\title{
PRE-ELIMINARY STUDY OF IKAN (FISH ONLINE INVESTMENT) PROTOPY BASED ON WEB APPLICATION USING AGILE SCRUM
}

\author{
Wina Permana Sari ${ }^{1}$, Hanugra Aulia Sidharta ${ }^{2}$ \\ 1,2 Program Studi Ilmu Komputer Universitas Bina Nusantara Jakarta, Indonesia \\ E-mail: wina.sari001@ binus.ac.id
}

Submission date: 2020-05-02

Accepted date: $2020-05-10$

\begin{abstract}
Ministry of Health (DepKes) of the Republic of Indonesia, the main problem which is an obstacle for fishermen in a small business in the field of fisheries as a matter of capital. Capital problems that can be reported according to: difficulty in accessing, capital requirements for convoluted capital, to the public ignorance of the relevant institutions. Diverting, taking a few people who then use independent capital, or make loans through informal financial institutions. The problems encountered by the fishermen make them confused and difficult to find when they need the micro business. However, this certainly can be overcome, considering how technology has developed rapidly now. In terms of technological developments, we have now switched to the era of the industrial revolution 4.0, while information and information technology has been highly developed. Seeing the facts that exist in society, technology can be used to facilitate humans in carrying out daily activities. Therefore, in view of the facts above, the writer wants to make a fisheries investment application for investors to invest the capital they need for microfisheries businesses and vice versa. The purpose of this research is to create a mobile and web-based Fisheries Investment application (using bootstrap) which the writer will name "Fish" taken from a fisheries investment developed using stages appropriate to the Agile Scrum method based on knowledge within in the field of Software Engineering and is equipped with basic planning models for formation systems, such as: Business Model Canvas (BMC), Use Cases, Activity Diagrams, and Mock-Ups. The results of this study can be used to help organize the distribution of prototype development scenarios to completion with a time schedule.
\end{abstract}

Keywords: Technology, Fish, Mobile, Web.

\begin{abstract}
ABSTRAK
Departemen Kesehatan (DepKes) Republik Indonesia, masalah utama yang seringkali menjadi penghambat bagi nelayan dalam membuka suatu usaha kecil dalam bidang perikanan ialah masalah permodalan. Masalah permodalan tersebut dapat dijabarkan menjadi: sulitnya akses, persyaratan penerimaan permodalan yang berbelit-belit, hingga ketidaktahuan masyarakat mengenai lembaga pendanaan. Akibatnya, tak sedikit masyarakat yang kemudian menggunakan modal mandiri, ataupun melakukan peminjaman melalui lembaga keuangan yang informal. Masalah yang didapatkan para nelayan tersebut seringkali membuat mereka bingung dan bahkan kesusahan saat membuka usaha mikro mereka tersebut. Namun, hal tersebut tentu dapat diatasi, mengingat bagaimana teknologi sudah berkembang pesat saat ini. Dari segi perkembangan teknologi, saat ini kita memasuki era revolusi industri 4.0, dimana teknologi informasi dan informasi sudah sangat berkembang. Melihat fakta yang ada di masyarakat, teknologi dapat digunakan untuk mempermudah manusia dalam melakukan kegiatan sehari-hari. Oleh karena itu, menilik fakta-fakta diatas, maka penulis ingin menciptakan sebuah aplikasi investasi perikanan sebagai wadah bagi para investor untuk menanamkan modal mereka didalam usaha mikro para nelayan dan sebaliknya. Tujuan dari penelitian ini ialah untuk menciptakan aplikasi Investasi Perikanan berbasis mobile dan web (dengan menggunakan bootstrap) yang akan penulis namai "Ikan" yang diambil dari Investasi perikanan secara bertahap menggunakan tahapan-tahapan yang sesuai dalam metode Agile Scrum yang berbasis pada pengetahuan di dalam bidang Software Engineering dan dilengkapi dengan modelmodel rancangan dasar untuk pembentukkan sistem, seperti: Business Model Canvas (BMC), Use Case, Activity Diagram, dan Mock-Up. Hasil dari penelitian ini dapat digunakan untuk membantu mengatur manajemen sirkulasi pembagian scenario kegiatan pembangunan prototipe sampai selesai sesui dengan timeline schedule.
\end{abstract}

Kata Kunci: Teknologi, Ikan, Mobile, Web. 


\section{PENDAHULUAN}

Indonesia merupakan negara yang cukup besar di benua Asia. Indonesia sendiri mempunyai luas wilayah sebesar 7,81 juta $\mathrm{km} 2$, dengan pembagian $41,6 \%(3,25$ juta $\mathrm{km} 2)$ adalah wilayah lautan, 2,55 juta km2 adalah Zona Ekonomi Eksklusif, dan 2,01 juta km2 adalah daratan (Badan Pembinaan Hukum Sosial, 2015).

Saat ini, budidaya di Indonesia dalam sektor perikanan cenderung meningkat. Hal ini diawali oleh adanya pemikiran para nelayan serta masyarakat di sekitar daerah lautan mengenai memanfaatkan potensial laut dan segala isinya dengan cara membuka suatu usaha budidaya dalam sektor perikanan. Berbicara tentang peningkatan dalam sektor perikanan, hal tersebut didukung dengan data real dari website resmi Direktorat Jenderal Perikanan Budaya, yang mengutip data secara langsung dari Badan Pusat Statistik (BPS) yang menyatakan bahwa: pertumbuhan PDB Nasional sektor perikanan tahun 2017 tercatat sebesar $6,75 \%$ atau naik sebesar 31 persen dari tahun 2016. Selain itu, Direktur Jenderal Perikanan Budidaya, Slamet Soebjakto, juga memastikan, bahwa kinerja PDB Sektor perikanan, ditopang oleh volume produksi perikanan budidaya, dalam 5 (lima) tahun terakhir (2013-2017) tercatat tumbuh rata-rata sebesar 5,11\%, dimana tahun 2017 angka sementara volume produksi perikanan budidaya mencapai 16,16 juta ton. Fakta-fakta diatas menunjukkan bahwa ada peluang besar dari produk budidaya perikanan di Indonesia untuk bersaing dalam perdagangan global karena angka-angka diatas akan terus bertambah dari tahun ke tahun (Direktorat Jenderal Perikanan Budaya, 2018).

Masalah utama yang seringkali menjadi penghambat bagi nelayan dalam membuka usaha kecil dalam bidang perikanan ialah masalah permodalan. Masalah permodalan tersebut dapat dijabarkan menjadi: sulitnya akses, persyaratan penerimaan permodalan yang berbelit-belit, hingga ketidaktahuan masyarakat mengenai lembaga pendanaan. Akibatnya tidak sedikit masyarakat yang kemudian menggunakan modal mandiri, ataupun melakukan peminjaman melalui lembaga keuangan yang informal (Kementerian Kesehatan Republik Indonesia, 2018).

Sistem adalah suatu bagian sistem Komputer yang tidak berwujud. Salah satu contoh software yang sering dijumpai di kehidupan seharihari ialah program komputer. Menurut (Pressman, 2010) mengatakan bahwa suatu software zaman sekarang memiliki peranan ganda, yaitu sebagai produk dan sebagai sarana pengirim produk/vehicle. Sebagai suatu produk, software melakukan suatu koordinasi dengan hardware untuk memberikan potensi komputasi, sedangkan sebagai vehicle, software bertindak sebagai dasar untuk kontrol komputer (sistem operasi), komunikasi informasi (jaringan), dan penciptaan dan kontrol program lain (alat dan lingkungan perangkat lunak).

Menurut (Remick, 2011) Web based Application mengatakan bahwa suatu web-based application adalah sebuah aplikasi yang menggunakan dapat diakses dengan menggunakan bantuan browser sehingga aplikasi dapat dijalankan dengan cara mengakses suatu jaringan computer/computer network.

Menurut (Pressman, 2010) Scrum merupakan berasal dari satu kegiatan yang terjadi dalam pertandingan rugby. Scrum sendiri sejatinya adalah sebuah agile software development method yang dikembangkan oleh Jeff Sutherland dan development team nya di awal 1990-an. Dalam beberapa tahun terakhir, pengembangan lebih lanjut metode scrum telah dilakukan oleh Schwaber dan Beedle.

Prinsip kerja dari metode scrum ialah konsisten dengan manifesto agile dan digunakan untuk membimbing kegiatan pengembangan dalam suatu proses yang menggabungkan framework activities berikut: requirements, analysis, design, evolution, dan delivery. Dalam setiap framework activity, tugas kerja terjadi dalam sebuah pola proses tertentu yang disebut dengan sprint. Pekerjaan yang dilakukan dalam sebuah sprint disesuaikan dengan masalah-masalah yang dihadapi dan didefinisikan serta sering dimodifikasi secara real time oleh tim Scrum.

Metode Scrum menekankan adanya penggunaan satu set software process patterns/pola proses perangkat lunak yang sudah terbukti efektif dengan jadwal-jadwal yang ketat, adanya perubahan persyaratan/requirement changes, dan dalam kondisi kritikal suatu bisnis/business criticality. Masing-masing pola proses ini mendefinisikan serangkaian tindakan pengembangan:

1. Backlog: berisi sejumlah daftar-daftar requirements yang memberikan business value bagi pelanggan. Items dapat ditambahkan kedalam suatu backlog kapan saja, kemudian product manager akan menilai backlog tersebut dan melakukan update prioritas sesuai kebutuhan.

2. Sprints: terdiri dari unit-unit kerja /work units untuk mencapai sebuah requirement dalam sebuah backlog yang harus disesuaikan dengan waktu.

3. Scrum meetings: adalah pertemuan singkat (sekitar 15 menit) yang diselenggarakan oleh Scrum team dengan cakupan pertanyaan yang meliputi apa saja yang dilakukan oleh tim, halangan apa yang ditemui oleh tim, dan 
rencana/planning selanjutnya. Dalam rapat ini pemimpin nya ialah Scrum master.

4. Demos: memberikan progress suatu software kepada pelanggan sehingga fitur-fitur yang telah dikerjakan dalam tim dapat dievaluasi oleh pelanggan. Dalam proses demo ini, tidak semua fitur yang telah direncanakan dapat ditunjukkan kepada pelanggan.

Masalah yang didapatkan para nelayan tersebut seringkali membuat mereka bingung dan bahkan kesusahan saat membuka usaha mikro mereka tersebut. Namun, hal tersebut tentu dapat diatasi, mengingat bagaimana teknologi sudah berkembang pesat saat ini.

Dari segi perkembangan teknologi, saat ini kita memasuki era revolusi industri 4.0, dimana teknologi informasi dan informasi sudah sangat berkembang. Melihat fakta yang ada di masyarakat, teknologi dapat digunakan untuk mempermudah manusia dalam melakukan kegiatan sehari-hari. Oleh karena itu, menilik fakta-fakta diatas, maka penulis ingin menciptakan sebuah aplikasi investasi perikanan sebagai wadah bagi para investor untuk menanamkan modal mereka didalam usaha mikro para nelayan, dan sebaliknya. Penulis ingin menciptakan aplikasi Investasi Perikanan berbasis mobile dan web (dengan menggunakan bootstrap) yang akan penulis namai "Ikan" yang diambil dari Investasi perikanan secara bertahap menggunakan tahapan-tahapan yang sesuai dalam metode Agile Scrum yang berbasis pada pengetahuan di dalam bidang Software Engineering dan dilengkapi dengan model-model rancangan dasar untuk pembentukkan sistem, seperti: Business Model Canvas (BMC), Use Case, Activity Diagram, dan Mock-up.

\section{METODE PENELITIAN}

\section{Requirement model}

Melalui requirement modeling, penulis pun berusaha untuk memahami kebutuhan pengguna, baik indirect user (pemilik usaha kecil budidaya perikanan), maupun direct user (investor).

Berikut tahapan-tahapan untuk menentukan requirement-requirement dari target user :

1. Inception: pada tahapan ini, penulis pun melakukan sejumlah pengamatan terhadap masalah-masalah real di masyarakat. Selanjutnya, penulis berusaha untuk memiliki pemahaman dasar mengenai masalah-masalah tersebut.

2. Elicitation: setelah melalui tahapan inception, pada tahapan ini kita berusaha untuk mengambil sejumlah pendapat dari target user, baik dari pihak investor, maupun pihak pemilik usaha kecil budidaya perikanan. Setelah itu, kita menanyakan kebutuhan requirement mereka.
3. Elaboration: melalui tahap elaboration, penulis telah mengetahui berbagai requirement yang telah diajukan oleh target user, selanjutnya, di tahapan elaboration kita mengerjakan secara lebih mendetail berdasarkan pada requirementrequirement yang sudah kita dapatkan dari tahapan sebelumnya. Di tahapan ini kita kemudian melakukan analisis lebih lanjut dengan model-model analisis, untuk memahami segala aspek-aspek requirement yang diterima dari target user.

4. Negotiation: sesuai dengan nama tahapannya, pada tahapan ini kita melakukan proses negosiasi dengan tim penulis dan pihak investor, untuk menyepakati bagaimana realisasi sistem aplikasi yang diinginkan.

5. Specification: pada tahapan ini penulis lebih dalam lagi mendefinisikan requirementrequirement yang sudah diterima baik secara informal maupun formal, menggunakan diagram-diagram, seperti: Unified Modeling Language (UML) diagram. Dengan menggunakan pendefinisian menggunakan diagram, maka developer/penulis akan lebih mudah dalam membangun sebuah aplikasi yang berdasar pada requirement customer.

6. Validation: pada tahapan ini penulis mengulas kembali apakah sistem aplikasi yang penulis bangun sudah dapat dikatakan memenuhi requirement dari target user. Pada tahapan ini, juga dilakukan testing untuk mengetahui apakah ada kecacatan, ambiguitas, konflik, dan bahkan error-error pada sistem.

7. Requirements Management: pada akhirnya, di tahapan ini penulis sebagai developer juga senantiasa melakukan manajemen requirement untuk berjaga-jaga apabila sewaktu-waktu terjadi perubahan requirement dari target user.

\section{Analisa dan Perancangan}

Metode yang digunakan dalam analisa dan perancangan adalah BMC (Business Cancas Model) dan UML (Unified Modelling Language).

Menurut (Osterwalder, 2010) mengatakan bahwa Business Model Canvas (BMC) ialah berdasarkan pada suatu business model yang terdiri dari 9 blok. Sembilan blok itu mencakupi 4 area utama dari sebuah bisnis, yaitu: customers, penawaran, infrastruktur, dan kelayakan finansial. Business model ini merupakan sebuah rancangan dasar untuk strategi yang akan diimplementasikan melalui suatu suatu struktur, proses, dan sistem organisasi. Kesembilan blok tersebut terdiri dari: Customer Segements, Value Propositions, Channels, Customer Relationships, Revenue Streams, Key Resources, Key Activities, Key 
Partnerships, dan Cost Structure. UML adalah salah satu metode permodelan dalam perancangan sebuah sistem berorientasi objek.

Menurut (Satzinger, J., Robert Jackson, 2009) menyatakan bahwa Use Case Diagram merupakan diagram yang digunakan untuk mengidentifikasi bagaimana suatu sistem akan digunakan. Penulis membuat BMC dan UML berdasarkan alur yang ada pada aplikasi Ikan, dengan cara menganalisa dan menerjemahkan hasil analisa ke dalam bentuk salah satu UML yaitu Diagram Use Case.

\section{HASIL DAN PEMBAHASAN}

\section{Analisa Masalah pada Sistem berjalan}

Dari hasil studi literature dan observasi yaitu:

1. Minimnya modal yang dimiliki para peternak ikan kemudian minimnya pengetahuan para peternak mengenai terobosan apa saja yang bisa dilakukan untuk mendapatkan hasil yang maksimal dengan perawatan yang tidak membuat peternak merugi.

2. Rendahnya harga beli yang ditawarkan oleh para rentenir

3. lahan tambak perikanan yang luas namun teknologi yang masih sangat minim khususnya di area malang.

\section{Solusi Permasalahan}

Dari hasil analisa ini membuka sebuah solusi dari gap tersebut untuk menjembatani antara para peternak ikan, udang, maupun hewan air lainnya dengan para investor yang bisa berasal dari berbagai kalangan.

\section{Analisa dan Perancangan}

Berikut ini adalah Use Case Diagram dan Business Model Canvas serta MokeUp tampilan untuk aplikasi investasi perikanan, Terdapat dua user dalam prototype ini yaitu investor (masyarakat berbagai kalangan) dan admin.

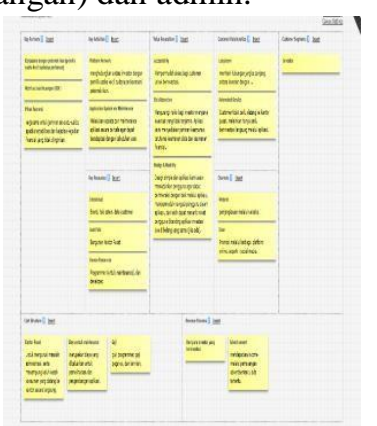

Sumber : (Wina Permana Sari, 2019)

Gambar 1. Diagram Use Case Prototipe MokUp Aplikasi Ikan (user investor)

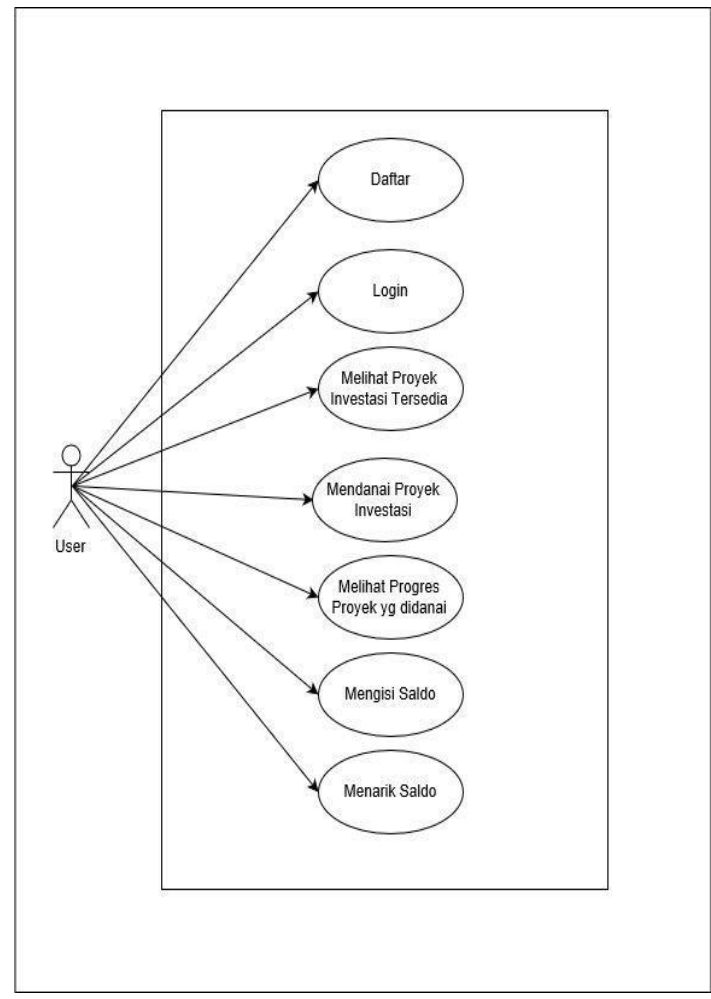

Sumber : (Wina Permana Sari, 2019)

Gambar 2. Diagram Use Case Prototipe MokeUp Aplikasi Ikan (admin)

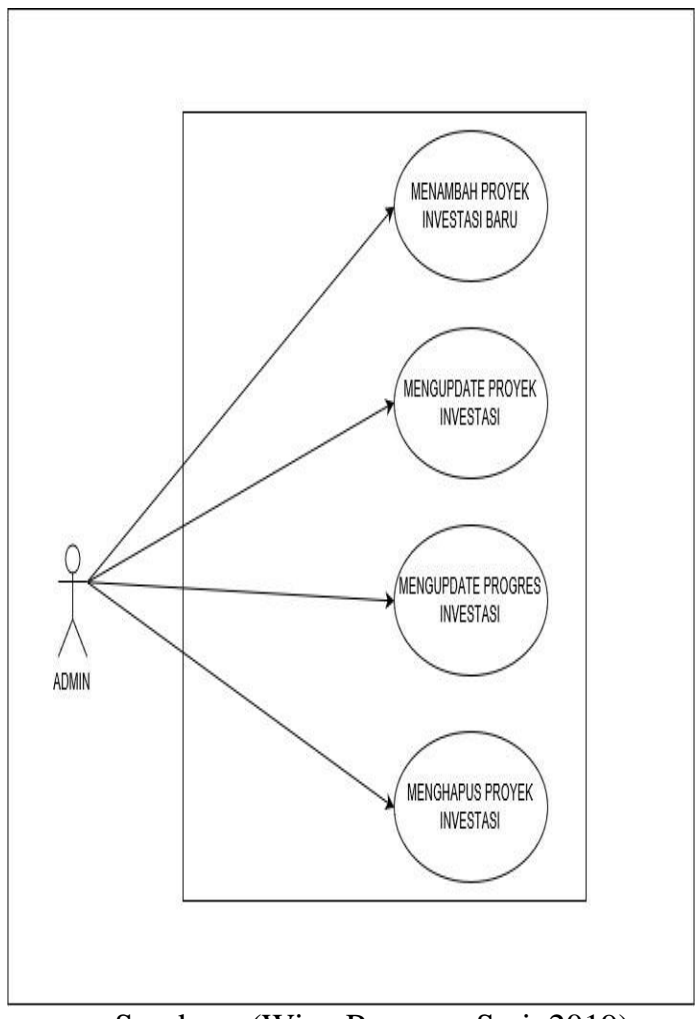

Sumber : (Wina Permana Sari, 2019)

Gambar 3. Busines Model Canvas Prototipe MokUp Aplikasi Ikan 


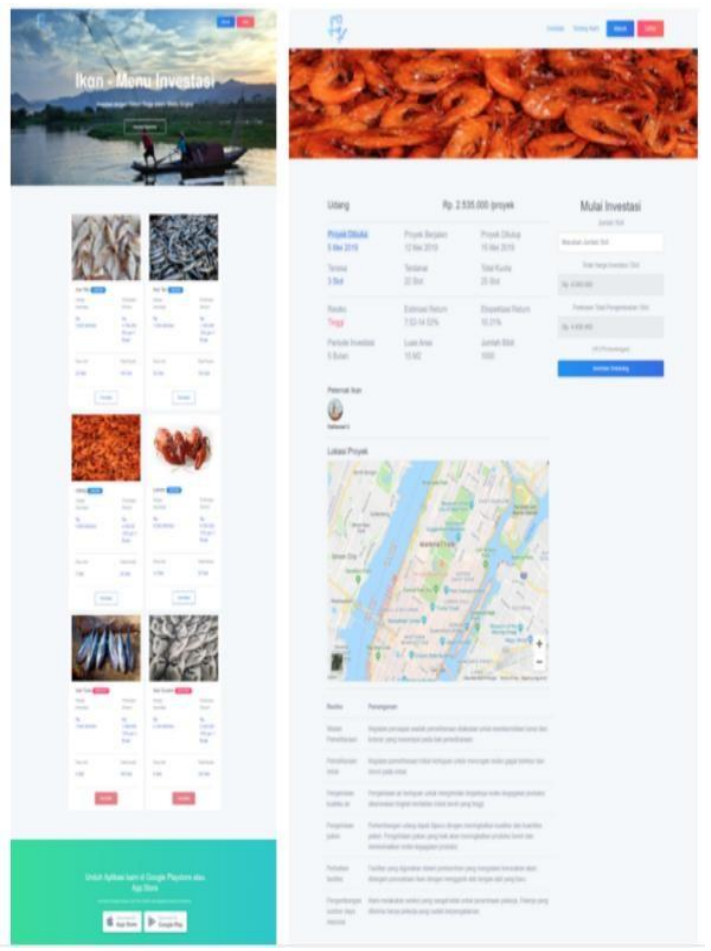

Sumber : (Wina Permana Sari, 2019)

Gambar 4. Prototipe MokUp Aplikasi Ikan

\section{KESIMPULAN}

Berdasarkan hasil pre-eliminary studi mengenai analisa serta pengembangan yang dilakukan untuk prototipe aplikasi ikan maka dapat disimpulkan bahwa:
Perancangan prototype ini dapat diimplementasikan dengan berbasis aplikasi web Metode scrum dapat digunakan untuk membantu mengatur manajemen sirkulasi pembagian scenario kegiatan pembangunan prototipe sampai selesai sesui dengan timeline schedule. Prototype Aplikasi ini memiliki peluang bisnis dan membuka peluang bagi para masyarakat luas (selaku investor), kemudian nelayan dan developer applikasi ini sendiri.

\section{DAFTAR PUSTAKA}

Badan Pembinaan Hukum Sosial. (2015). Indonesia Merupakan Negara Kepulauan Terbesar di Dunia.

Direktorat Jenderal Perikanan Budaya. (2018). Subsektor Perikanan Budidaya Sepanjang Tahun 2017 Menunjukkan Kinerja Positif.

Kementerian Kesehatan Republik Indonesia.(2018). Pembiayaan Mikro Menjadi Solusi Mudah Permodalan Nelayan.

Osterwalder, A. and Y. P. (2010). Business Model Generation. John Wiley and Sons Ltd.

Pressman, R. S. (2010). Software Engineering: A Practitioner's Approach. McGraw-Hill Higher Education.

Remick, J. (2011). What Is a Web App? Here's Our Definition. http://web.appstorm.net

Satzinger, J., Robert Jackson, and S. B. (2009). Systems Analysis \& Design In a Changing World. Course Technology.

Wina Permana Sari, H. A. S. (2019). Pre-Eliminary Study Of Ikan (Fish Online Investment) Protopy Based On Web Application Using Agile Scrum. 
